\title{
Women in Brazilian neurosurgery
}

\author{
Henrique S. Ivamoto ${ }^{1}$ \\ Santa Casa da Misericórdia de Santos, Brazil.
}

\begin{abstract}
Medicine remained as a male profession during many centuries, but the proportion of women rose steadily during the second part of the $20^{\text {th }}$ century in the world and in Brazil. In 2006 they became the majority (51.75\%) of the new physicians licensed by the Regional Council of Medicine of the State of São Paulo. Nevertheless, the proportion of women in Neurosurgery and in directive posts in entities of the specialty in Brazil continue very low or absent. Data obtained from the Brazilian Society of Neurosurgery and the Brazilian Academy of Neurosurgery are very similar to those of the American counterparts, like the proportion of women among the associates, around $5 \%$, and one single female chief of a service certified for training in each country. Authors from WINS, an American entity, reported several problems suffered by female neurosurgeons, including gender discrimination. Such occurrences, as reported in online news, should alert against discriminatory attitudes.
\end{abstract}

\section{KEY WORDS}

Women physicians. Neurosurgery. Statistics.

\section{RESUMO}

Mulheres na neurocirurgia no Brasil

A medicina remanesceu como uma profissão masculina durante muitos séculos, mas a proporção de mulheres aumentou constantemente durante a segunda metade do século $X X$ no mundo e no Brasil. Em 2006, elas passaram a constituir a maioria (51,75\%) dos novos médicos licenciados pelo Conselho Regional de Medicina do Estado de São Paulo. Todavia, a proporção de mulheres na neurocirurgia e em cargos diretivos de entidades da especialidade no Brasil continua muito baixa ou ausente. Dados obtidos da Sociedade Brasileira de Neurocirurgia e da Academia Brasileira de Neurocirurgia são muito semelhantes aos das congêneres americanas, como a proporção de mulheres entre as associadas, em torno de 5\%, e uma única chefe de serviço credenciado para treinamento em cada país. Autoras da WINS, entidade americana, relataram diversos problemas enfrentados pelas neurocirurgiãs, incluindo discriminações de gênero. Ocorrências dessa natureza, noticiadas em jornais eletrônicos, devem alertar contra atitudes discriminatórias.

\section{PALAVRAS-CHAVE}

Médicas. Neurocirurgia. Estatísticas.

\section{Introduction}

Although the number of women graduating in Medicine is surpassing that of men, few are the female neurosurgeons or trainees in Brazil. A study carried out by female neurosurgeons in the United States reports data that are similar to the Brazilian and points to gender inequity in training programs, in practice and in the ascension to leadership posts in that country. ${ }^{2}$

\section{Women in medicine}

Hatshepsut, whose name means "the most notable among the noble ladies", lived in the 15 th century b.C., became famous because of her beauty and intelligence and was thought to have had medical knowledge. ${ }^{6,7,11}$ She was the only direct heir of her father, the pharaoh, who died, but her leadership was not accepted because she was a woman. She had to get married to a half-brother, who took charge of the government. Widowing soon, she became the temporary regent during the minority of her stepson and, in order to overcome the obstacles to become pharaoh, she used an intelligent strategy: she obtained the support of the priests who passed to publicize her idea that she was a semi-goddess, the eldest of the children of god Amon and his representative on earth. With the religious support, she ruled Egypt, leading it to one of the most prosperous phases of its history, encouraging the development of architecture and other arts and sciences. Hatshepsut became known for her successful struggle against the 
historical rejection of female leadership that subsists into postmodernity.

In Greek mythology, Aesculapius, the god of healing, had the assistance of his wife Epione, who relieved pain, and of two daughters, Panacea, who knew all the medicines and treatments and Hygeia, the goddess of health and disease prevention.

During the Middle Ages and afterwards, in several European countries, women were kept away from medical practice by doctors and by the rest of society, who allowed them to act only as aids, nurses or midwives.

In the early 19th century in England and the United States, the first students to enroll in medical schools were targeted with insults and aggressions. ${ }^{14}$ When Harriot Hunt (1805-1875) tried to enroll in medical school at Harvard with the approval of the dean and teachers, students prevented her entry and she ended up graduating as a homeopathic physician in Syracuse.

After being rejected by eleven institutions, Elizabeth Blackwell (1821-1910) enrolled in a small medical school in New York State, thanks to an artifice that the director had used to deceive the students. After graduation, she began fighting for the rights of the female physicians in the United States, England and France.

Through the Leoncio de Carvalho Reform, Brazilian Emperor D. Pedro II signed the Decree 7247 on April 29,1879 , that gave "the freedom and right of women to attend courses at the faculties and obtain academic degrees", opening the doors of higher education, according to Alberto Silva (apud Piccinini ${ }^{13}$ ). The first Brazilian woman graduated in medicine was Dr. Maria Augusto Generoso Estrela (1860-1948), who studied in New York and revalidated her diploma in Brazil in 1882. The first female physician to graduate in Brazil was Dr. Rita Lobato Velho Lopes (1867-1954), who entered the medical school of Rio de Janeiro and concluded in the other located in Salvador in 1887. These and other pioneers suffered discrimination.

The male dominance continues, but the number of women in medicine has grown in Brazil, United States and other Countries. In the last decades, the Regional Council of Medicine of the State of São Paulo ${ }^{5,12}$ (Cremesp) has registered a steady increase in the number of women among the new licensees in the State, surpassing the number of men by the first time in 2006 (Table 1). Of the 101,087 physicians in activity in the State of São Paulo in January, 2010, men still are the majority (60\%), but a balance is estimated to occur within a decade. The number of women is already larger in 14 of the 53 officially recognized medical specialties. In addition to neurosurgery, other specialties, including orthopedics, thoracic surgery and urology, have a small proportion of female surgeons.
Table 1

Numbers of new physician licensees in the Regional Council of Medicine of the State of São Paulo (Cremesp) and the percentage of women

\begin{tabular}{lcccc} 
Year & Total & Men & Women & Women $(\%)$ \\
1980 & 2,267 & 1,506 & 761 & 33.57 \\
1990 & 2,293 & 1,298 & 995 & 43.39 \\
2000 & 2,562 & 1,419 & 1,143 & 44.61 \\
2006 & 3,030 & 1,462 & 1,568 & 51.75 \\
2007 & 2,449 & 1,130 & 1,319 & 53.86 \\
2008 & 3,072 & 1,445 & 1,627 & 52.96 \\
2009 & 3,029 & 1,384 & 1,645 & 54.31 \\
\hline
\end{tabular}

\section{Women in neurosurgery in the United States}

Women in Neurosurgery (WINS) is an American neurosurgical entity that encourages the entry of women in the specialty and helps them overcome barriers to their development. According to a survey by Benzil ${ }^{2}$ and other members of this association, by early 2007 the American Academy of Neurological Surgeons had admitted only one woman and the Society of Neurological Surgeons (SNS) only two. No woman had been president of the American Association of Neurological Surgeons or of the Congress of Neurological Surgeons (CNS), or been member of the American Board of Neurological Surgery or of the Neurological Surgery Residency Review Committee of the Accreditation Council for Graduate Medical Education. The last two entities are responsible for the certification of specialists and for the control of residencies.

According to that article, female doctors who can be part of some specialty dominated by men often become victims of the phenomenon they call "glass house", that isolates them from other team members. Another form of discrimination they identify is the "glass ceiling", that prevents their rise in their professional and academic careers and within neurosurgical organizations. Besides discrimination, another explanation they give for the small number of women residents in neurosurgery is the insufficient number of female neurosurgeons that could serve as models for the students. Dr. Benzil ${ }^{3}$ kindly provided us further data on women in neurosurgery in the United States. The book "Heart of a Lion, Hands of a Woman: What Women Neurosurgeons Do", details related issues. According to recent online news from the United States, some female neurosurgeons have sought the Justice for gender discrimination, a warning to avoid improper attitudes or remarks. 


\section{Women in neurosurgery in Brazil}

The first woman to obtain the specialist certification from the Brazilian Society of Neurosurgery (SBN) was Dr. Cleyde Cley da Silva Vescio, at the exam held in Campinas in 1974 (Table 2). ${ }^{15}$ She had graduated from the Faculty of Medicine of the University of São Paulo in 1969, where she undertook her residency and mastership, becoming a member of the SBN in 1976 and chief of the Neurosurgery Service of the Hospital Matarazzo in São Paulo.

According to data provided by the secretariat of the Brazilian Academy of Neurosurgery ${ }^{1}(\mathrm{ABNc})$, in February 2010 there were 808 full members, 42 of them female. The first woman, a member since 1984, is Dr. Carla Renata Aparecida Vieira Stella, currently the chief of the Department of Neurology and Neurosurgery of the Hospital Casa de Saúde in the city of Campinas. Three female neurosurgeons have held or hold a position in the board of the entity, as secretaries, doctors Lilian Bridges Pinto Machado, Ana Luisa Machado de Oliveira and Mercia Jeanne Duarte Bezerra.

Brazilian data ${ }^{1,15}$ are very similar to those of the United States. ${ }^{3,4}$ The proportion of women in the SBN and in the $\mathrm{ABNc}$ are very similar to that found in the American Association of Neurological Surgeons (AANS) (Table 3), around 5\%, and only one woman has taken charge of a service accredited for training in each country (Tables 4 and 5).

Table 2
First women approved for certification as specialists
by the SBN or by the ABNS (American Board of
Neurological Surgery) and year of the exams

Table 5

First women who became chiefs of services certified for training by the ABNS or by the $S B N$

$\begin{array}{lccc}\text { Entity } & \text { Female chiefs } & \text { Institution } & \text { Year } \\ \text { ABNS } & \text { Dr. Karin } & \text { University of } & 2005 \\ & \text { Muraszko } & \text { Michigan } & \\ \text { SBN } & \begin{array}{c}\text { Dr. Rosilene } \\ \text { Morales }\end{array} & \begin{array}{c}\text { Santa Casa } \\ \text { de Santos }\end{array} & 2010 \\ & & & \end{array}$

During the quadrennial election for the posts of chiefs of services of the hospital Santa Casa da Misericórdia de Santos, occurred in January 2010, Dr. Rosilene Morales, the only female neurosurgeon in the institution, was elected to occupy the post in the Service of Neurosurgery. Because we had not heard of a female neurosurgeon being the chief of a service with an accredited program, the SBN was consulted. The query was answered by Dr. Samuel Tau Zymberg ${ }^{15}$ : among its 1796 full members, 98 are female, and to date, no woman had been chief of a service licensed for training, so the case was an unprecedented event in the history of the Brazilian Society of Neurosurgery. On several previous occasions, Dr. Morales had assumed the post, but temporarily, acting as substitute.

The Santa Casa da Misericórdia de Santos, the oldest Brazilian hospital, founded in 1543 by Brás Cubas, has always been used for the practical teaching of medicine and other health disciplines, a tradition common to all the Santa Casa da Misericórdia hospitals in the Country. ${ }^{8,10}$ One of its first apprentices was the young Jesuit novice José de Anchieta, who also stands as one of the founders of the village of São Paulo. The Misericórdia of Santos counted with the work of Friar Gaspar, the Andrada brothers, Claudio Luiz da Costa, Martins Fontes, Cerqueira Falcão and other distinguished Brazilian personalities. The Neurosurgery Service was established in 1952, initially as a section, under the direction of Dr. Antonio Ablas Filho, a prominent humanist who received an award from the Vatican and, after his death, had his name given to a public school in the city. Currently, the service counts with a staff of nine neurosurgeons and five trainees, besides a team of physicians of the 10 bed neurosurgical ICU. The hospital is the largest in the coastal region of the State and the Service is accredited for training by the SBN and the by the Brazilian Ministry of Education and Culture.

After training in the Neurosurgery Service, Dr. Rosilene Morales was admitted as an attending neurosurgeon in 1986 and received additional training at the Universite de Grenoble, France. Lately, she has been visiting the service for epilepsy surgery of Dr. Arthur Cukiert in the city of São Paulo. Her dedication to the patients led to the publication of the article "Women 
physicians, paternal mothers, anonymous heroines". 9 She is member of the SBN, advisor to the Brazilian Society of History of Medicine, cultural director of the Teaching Center of the Santa Casa of Santos, assistant professor at the Metropolitan University of Santos (Unimes), and holds a Master in Education degree, issued by the Catholic University of Santos.

In addition to the difficulties pointed out by WINS in the US, it should be recalled that the required training in Neurosurgery is long, surgeries are complex and tiresome, many cases are serious and urgent, deaths and sequelae are common, the media publicizes the concept that medicine is an exact science, the patients expect for mathematical results, the Brazilian society is becoming litigious, the fees are low and inconsistent with the high responsibilities. Several factors discourage young doctors from choosing the specialty in Brazil and stimulate early withdrawal from surgical activities.

\section{Conclusion}

When some directors of the SBN and of the Brazilian Society of History of Medicine were informed of the election of a woman as chief of a training service in Santos, a new fact in the history of Neurosurgery in Brazil and a further step towards the full emancipation of the female physicians in the Country, they answered with greetings and wishing for the best in her mission. In keeping with the current trend, the Hippocratic art should, in the coming years, be numerically dominated in all areas by the disciples of Epione, Hygeia and Panacea, and will have women like Hatshepsut to inspire them in their struggles against the barriers that still subsist.

We thank Ms. Sabrina Fernandes Monteiro (SBN) and Ms. Liene França Bezerra $(\mathrm{ABNc})$ for the statistical information.

\section{References}

1. Academia Brasileira de Neurocirurgia Secretariat. Electronic communication in February 2010.

2. Benzil DL, Abosch A, Germano I, Gilmer H, Maraire JN, Muraszko K, et al. The future of neurosurgery: a white paper on the recruitment and retention of women in neurosurgery. J Neurosurg. 2008;109:378-86.

3. Benzil DL. Electronic mails. February 2010.

4. Benzil DL, Muraszko KM. Heart of a lion, hands of a woman: what women neurosurgeons do. USA: The Donning Company Publishers; 2009.

5. Cremesp. Registra expressivo aumento de mulheres médicas nas últimas décadas. Available from: http://www. cremesp.org.br/?siteAcao $=$ Saladelmprensa\&acao $=c$ rm_midia\&id=517. (accessed on 21.01.2010).

6. DNA tests to confirm queen hatshepsut mummy. In: Science 2.0, News Staff, July 15, 2007. http://www.scientificblogging. com/news/dna_tests_to_confirm_queen_hatshepsut_ mummy (accessed on 22.01.2010).

7. Hatshepsut, in Biografias, UOL Educação. Available from: http://educacao.uol.com.br/biografias/hatshepsut.jhtm (accessed on 22.01.2010).

8. Ivamoto HS. A Santa Casa da Misericórdia de Santos: sinopse histórica. 1998(1);1:7-10. Available from: http:// www.actamedica. org.br/noticia. asp? codigo $=104$.

9. Ivamoto HS. Médicas, mães paternais, heroínas anônimas. A Tribuna. 1996:A-18.

10. Ivamoto HS, Morales R, Ivamoto LS, Vieira de Souza ESM. The Santas Casas da Misericórdia: Five centuries of philanthropy. 1998;1:11-3. Available from: http://www. actamedica.org. br/noticia. asp?codigo $=105$.

11. Lyons AS, Petrucelli II RJ. Medicine: an illustrated history. New York: Harry N. Abrams, Inc.; 1987. p. 170, 564-75.

12. Médicas inscritas são maioria em 2009. Jornal do Cremesp. 2010;267:5

13. Piccinini WJ. Mulheres na Medicina e na Psiquiatria Brasileira. Available from: http://www.polbr.med.br/arquivo/ wal1102.htm (accessed on 21.01.2010).

14. Rezende JM. O machismo na história do ensino superior. Available from: http://usuarios.cultura.com.br/jmrezende/ machismo.htm (accessed on 21.01.2010).

15. Sociedade Brasileira de Neurocirurgia Secretariat. Electronic communication in January and February 2010.

Endereço para correspondência

Henrique Seiji Ivamoto

Rua Vergueiro Steidel, 126/2

11040-270 - Santos, SP, Brasil

E-mail: hivamoto@yahoo.com.br 